\title{
Estimated length of soybean phenological stages
}

\section{Estimativa de duração das fases fenológicas da soja}

\author{
Ana Paula Rockenbach ${ }^{1 *}$; Braulio Otomar Caron²; Velci Queiróz de Souza ${ }^{3}$; \\ Elvis Felipe Elli'; ${ }^{4}$ Douglas Machado de Oliveira ${ }^{4}$; Gean Charles Monteiro ${ }^{5}$
}

\begin{abstract}
The use of modeling is a trend for agronomic science that aims to detect factors that could limit the growing practices and influence the potential yield of some crops. The objective of this study was to calculate the accumulated thermal time and estimate the phenological stages length of three soybean cultivars in two crop years, using agronomic models associated to meteorological variables. Two experiments were conducted in a field at the Agroclimatology Laboratory (LAGRO) of the Federal University of Santa Maria/UFSM, campus of Frederico Westphalen/RS, Brazil during the 2012/2013 and 2013/2014 crop years. A randomized block in a factorial scheme $6 \times 3$ with six spatial arrangements (45, crossed, 20, 20x40, 20x60 and 20x80 cm) and three cultivars with different cycles and growth habits (BMX Ativa RR/determinate, BMX Turbo RR/indeterminate and BMX Potência RR/indeterminate) with three replications were used for the experimental design. Sowing was held on 11/28/2012 and $12 / 02 / 2013$. The assessed phenological stages were sowing-emergence; emergence - final vegetative; final vegetative - full bloom; full bloom - physiological maturity. The duration of each stage was related to meteorological parameters: maximum temperature, minimum temperature, average temperature, rainfall, solar radiation, and thermal time. Air temperature influences soybean growth and development. The accumulated thermal time varies between years and among cultivars, and it is the main contributor to the estimated duration of the phenological stages.
\end{abstract}

Key words: Weather elements. Glycine max L. Merrill. Agronomic models. Thermal time. Temperature.

\section{Resumo}

A utilização de modelagem é uma das tendências da ciência agronômica que objetiva detectar os fatores que possam limitar o cultivo e influenciar no potencial de rendimento das culturas. O objetivo deste trabalho foi calcular a soma térmica acumulada e estimar a duração das fases fenológicas de três cultivares de soja em dois anos agrícola, por meio de modelos agronômicos associados às variáveis meteorológicas. Dois experimentos foram conduzidos no campo experimental do Laboratório de Agroclimatologia (LAGRO) da Universidade Federal de Santa Maria/UFSM, campus Frederico Westphalen/RS nos anos agrícolas de 2012/2013 e 2013/2014. O delineamento experimental usado foi de blocos casualizados em esquema fatorial $6 \times 3$, ou seja, seis arranjos espaciais (45, cruzado, 20, 20x40, 20x60 e 20x80 cm) e três cultivares de ciclos e hábito de crescimento distintos (BMX Ativa RR/determinada, BMX Turbo RR/indeterminada e BMX Potência RR/indeterminada) com três repetições. As semeaduras foram realizadas nos dias 28/11/2012 e 02/12/2013. As fases fenológicas

1 Discente Programa de Pós-Graduação em Agronomia, Universidade de Passo Fundo, UPF, Passo Fundo, RS, Brasil. E-mail: anapagronomia@yahoo.com.br

2 Prof., Universidade Federal de Santa Maria, UFSM, Frederico Westphalen, RS, Brasil. E-mail: otomarcaron@yahoo.com.br

3 Prof., Universidade Federal do Pampa, UNIPAMPA, Bagé, RS, Brasil. E-mail: velciq@gmail.com

4 Discentes, Universidade Federal de Santa Maria, UFSM, Frederico Westphalen, RS, Brasil. E-mail: elvisfelipeelli@yahoo.com; douglas.mdo@hotmail.com

5 Discente, Universidade Estadual Paulista Júlio de Mesquita Filho, UNESP, Botucatu, SP, Brasil. E-mail: gean.monteiro@yahoo. com.br

* Author for correspondence 
avaliadas foram: semeadura - emergência; emergência - vegetativo final; vegetativo final - floração plena; floração plena - maturação fisiológica. Relacionaram-se a duração de cada fase com os elementos meteorológicos: temperatura máxima, temperatura mínima, temperatura média, precipitação, radiação solar e soma térmica acumulada. A temperatura do ar influencia no crescimento e desenvolvimento da soja. A soma térmica acumulada varia nos anos e entre as cultivares, e é a principal contribuinte da estimativa de duração das fases fenológicas.

Palavras-chave: Elementos meteorológicos. Glycine max L. Merril. Modelos agronômicos. Soma térmica. Temperatura.

\section{Introduction}

The soybean (Glycine $\max$ L. Merril) is one of the main summer crops in the southern Brazil. Because of its higher protein and lipids content, it is featured in the national and international markets, influencing on the economy of small, medium and large farm companies. Nowadays the yield is been increased due to the constant application of new growing technologies, such as the use of genetic materials with high income potential (RICHTER et al., 2014; ZANON et al., 2015). Many factors can influence the crop development, among which the meteorological elements such as solar radiation, photoperiod, temperature and rainfall. These factors are responsible for the low period variation in the crop yield, due to the meteorological changes for each year (FERREIRA et al., 2007).

Among the changes, the air temperature is one of the meteorological elements that most influence the soybean development (FARIAS et al., 2007; FERREIRA et al., 2007; KANTOLIC, 2008; RODRIGUES et al., 2001; SETIYONO et al., 2007; SOUZA et al., 2013). The more adequate method to characterize plant growing and development is the thermal sum (accumulated thermal time), because this method take into consideration the air temperature effect (STRECK et al., 2008). The concept of degrees-day or thermal sum, and accumulated degrees-day or accumulated thermal time was introduced to overcome inadequacies of the calendar for the phenological events determination and for the crops agroclimatic zoning (SOUZA et al., 2013; WAGNER et al., 2011).

The air temperature can influence germination, growing, flowering, fructification, chemical reactions of respiration and photosynthesis, water absorption and nutrients (SEDIYAMA, 2009), influencing all phenological stages of the crop (ROCHA et al., 2012). Setiyono et al. (2007), estimating the minimum, optimum and maximum temperature for different soybean stages, observed different behavior for temperatures, when the minimum varied from 0 to $7^{\circ} \mathrm{C}$, the optimum from 21 to $32^{\circ} \mathrm{C}$ and the maximum from 38 to $45^{\circ} \mathrm{C}$, confirming the crop plasticity to different climatic conditions.

Besides its influence on the plant development, the meteorological elements, such as rainfall, solar radiation and minimum, average and maximum temperatures are important parameters for the agricultural zoning, sowing time, irrigation, yield estimative, credit and agricultural insurance (CARGNELUTTI FILHO et al., 2009). A way to evaluate elements contribution on the species development is by mathematical models. This is one of the agronomical science trends that aims to detect factors that could limit the cultivation and influence the crops productive potential, besides the prediction of the crop yield according to the plant development conditions. Thus, agrometeorological models related to crop growing, development and yield for different environments could provide informations that enable the agricultural sector to make important decisions (CARON et al., 2007). Ferreira et al. (2007) studying estimation models in soybean yield concluded that the use of the models was important to understand the productivity sources of variation, according to climatic variables. With the use of agronomic models is possible to infer the importance of meteorological elements on the crop 
development, defining the most important for the phenological stages.

A very important decision for the crop establishment is the choice of the cultivar that can have the better adaptation to the region conditions. In this process, one of the main characteristic to be evaluated is the growing habit. Until few years ago, the cultivars used in Brazil presented determinate growth habit, medium to late cycle and were sowing from November to December. Nowadays, the cultivars with indeterminate growth stands out between the soybean cultivars planted in Brazil, with the use of cultivars with a relative maturity between 5.0 and 6.5 , being planted from middle of October to November, making possible, in some places, a second summer harvest (STRIEDER et al., 2013). The long overlap period between the vegetative and reproductive stages of these cultivars can result in a greater adaptability to different sowing periods, with a higher recover capacity to short periods of stress, such as the absence of rain, excess of water in the soil and elevated temperatures (ZANON et al., 2015). Due to the meteorological variations that occurs during the crop year, the cultivars with indeterminate growth habit has stood out in the Brazilian market because the flowering occurs in a longer period, which justifies the studies about growth and development of new soybean cultivars.

The aim of this study was to calculate the accumulated thermal time and estimate the phenological stages length of three soybean cultivars submitted to spatial arrangements during two crop years using agronomic models associated to meteorological variables.

\section{Materials and Methods}

Two experiments were conducted in an experimental area of the Agroclimatology Laboratory (LAGRO) of the Federal University of Santa Maria/ UFSM, campus Frederico Westphalen/RS, Brazil (27023'48" S, 53025'45" O, $490 \mathrm{~m})$ during the 2012/2013 and 2013/2014 crop years. According to the climatic classification of Köppen, the region climate is considered Cfa. The meteorological data of air temperature, rainfall and global solar radiation were obtained in an automatic station of the National Institute of Meteorology (INMET).

The soil of the experimental area, that belongs to the Passo Fundo, RS, Brazil, mapping unity, is classified as a typical red dystrophic oxysol, with a clayey texture, deep and well drained (EMBRAPA, 2006). The experiment design was carried out with randomized blocks in a $6 \times 3$ factorial scheme, with six spatial arrangements (45, crossed, 20, 20x40, 20x60 and 20x80 cm) and three cultivars with different cycles and growing habits (BMX Ativa RR/ determinate, BMX Turbo RR/indeterminated and BMX Potência RR/indeterminated), with three repetitions with $6,75 \mathrm{~m}^{2}$ per plot, where five plants were evaluated during the cycle to determinate the phenological stages.

The sowing were realized at 11/28/2012 and $12 / 02 / 2013$ with the base fertilization applied in a manual form, according to the recommendations of the Commission for the soil chemistry and fertility (CQFS, 2004). The emergency was considered when $50 \%$ of the seedlings were emerged, on average at eight days after sowing and the thinning was carried out seven days after emergency, remaining 250.000 plants $\mathrm{ha}^{-1}$, for all treatments. The flowering was defined when $50 \%$ of the plants presented open flowers on the main stem, characterizing the R2 stage.

The weed, insects and plant diseases managements were realized according to the crop recommendations (COSTAMILAN et al., 2012). The plant development is followed by phenological scales and for the soybean crop and the used scale is from Fehr and Caviness (1977), that considers the number of nodes, number, size and pod filling, extending until the physiological maturity, classifying the stages as vegetative or reproductive.

The evaluated phenological stages were: sowing - emergency $(S-E)$, emergency-final vegetative 
(E - FV), final vegetative-full bloom (FV-FB), full bloom-physiologic maturity (FB - PM). The daily thermal sum $\left(\mathrm{dTS},{ }^{\circ} \mathrm{C}\right.$ day $\left.^{-1}\right)$ was calculated according to Gilmore and Rogers (1958): dTS: (Tavg-Tb), being Tavg the average of the daily air temperature, calculated with the means of the instant temperatures for each day, $\mathrm{Tb}$ the soybean base temperature, considered as $10^{\circ} \mathrm{C}$ (PIPER, 1996). The accumulated thermal time (AcTT, ${ }^{\circ} \mathrm{C}$ day $^{-1}$ ) for each phenological stage was calculated by: $\mathrm{AcTT}=\sum \mathrm{dTS}$.

To estimate each stage duration based on the meteorological variables, the general method for the multiple linear regression was used, with the Stepwise option at $15 \%$ of error probability with the use of the Statistical Analysis System Learning Edition 8,0 (SAS, 2003) software. The independent variables were the daily meteorological elements: maximum temperature (Tmax, $\left.{ }^{\circ} \mathrm{C}\right)$, minimum temperature ( $\mathrm{Tmin},{ }^{\circ} \mathrm{C}$ ), average temperature (Tavg, ${ }^{\circ} \mathrm{C}$ ), rainfall (rain, $\mathrm{mm}$ ), solar radiation ( $\mathrm{Rad}$, cal) and accumulated thermal time (AcTT, $\left.{ }^{\circ} \mathrm{C}_{\text {day }}{ }^{-1}\right)$; the dependent variables were the phenological stages of each cultivar. Specific agrometeorological models for each cultivar were estimated, when differed in the number of days in each phenological stage.

\section{Results and Discussion}

The minimum, maximum and average monthly temperature during the experiment period was similar for the two evaluated crop years (Figure $1)$. The average temperatures varied from 17 to $25^{\circ} \mathrm{C}$, being on the optimum range for the soybean development that varies from 20 to $33^{\circ} \mathrm{C}$, according to the phenologic stage (SETIYONO et al., 2007). The extremes for the maximum and minimum temperature occurred on February and April, respectively, for both evaluated crop years. This meteorological element is linked to plant growth and development, influencing on the accumulated thermal time during the experiment.

Figure 1. Air maximum, minimum and average temperature $\left({ }^{\circ} \mathrm{C}\right.$ ) by months during the $2012 / 2013$ (a) and 2013/2014 (b) crop years. UFSM, Frederico Westphalen/RS, 2015.
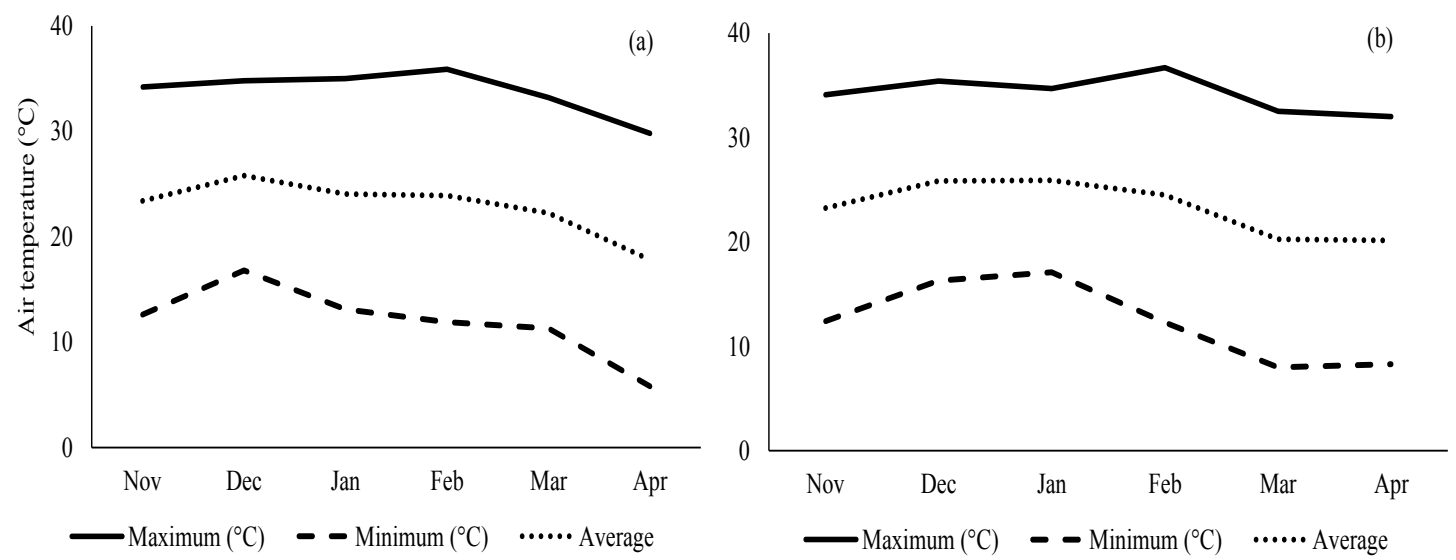
The cultivars did not responded to different spatial arrangements, for the accumulated thermal time and for the estimated duration of the stages. The accumulated thermal time on the phenological stages are presented on Figure 2. The stage sowingemergency, with nine days for all crop years and cultivars, resulted in a higher accumulated thermal time on the first crop year, when compared to the second crop year, for all studied cultivars. The first crop year was characterized for higher maximum and minimum temperatures when compared to the second crop year, for the same stage, consequently with a higher thermal time $\left(155.45^{\circ} \mathrm{C}\right.$ day $\left.^{-1}\right)$ during the 2012/2013 crop year, when compared to $2013 / 2014$ with $129.55^{\circ} \mathrm{C}_{\text {day }^{-1}}$ for all cultivars. The stage emergency - final vegetative had 44 to 54 days, varying according to the crop year and cultivar, and the accumulated thermal time varied from 600 to $800^{\circ} \mathrm{C}_{\text {day }}{ }^{-1}$, when all cultivars presented higher number of days for this stage during the first crop year. This data are in accordance to Souza et al. (2013) that also founded higher number of days and accumulated thermal time according to the crop year. This stage is extremely important for the beginning of flowering, since the stage number of days depends on the temperature and photoperiod, with a sufficiently short day length limit to induce flowering but long enough to prevent it (RODRIGUES et al., 2001). Besides that, the occurrence of low temperatures can increase the time before flowering (RODRIGUES et al., 2001). The flowering occurs when the temperatures are above $13^{\circ} \mathrm{C}$ (FARIAS et al., 2007). In this stage the temperature affects the development, establishment and growth of soybean reproductive organs (KANTOLIC, 2008), promoting damages to flowering and decreasing the pods holding capacity (FARIAS et al., 2009).

The stage final vegetative - full bloom occurred in seven days for both studied crop years for the cultivars BMX Ativa RR and BMX Turbo RR.
The cultivar BMX Potencia RR accumulated a higher thermal time over the second crop year for the same stage, comprising nine days. During this period, the optimum temperature is $32.4^{\circ} \mathrm{C}$ and the maximum is $41.9^{\circ} \mathrm{C}$ (SETIYONO et al., 2007) and it is important adequate temperatures in this stage, otherwise the flowers abortion can increase. For the both studies crop years, the maximum temperatures for this period was 35.9 and $37.9^{\circ} \mathrm{C}$, for the $2012 / 2013$ and 2013/2014 crop years, respectively. From the full bloom to the physiologic maturation only the cultivar BMX Turbo RR presented differences between the crop years, accumulating a higher thermal time during the second year with $956.15^{\circ} \mathrm{C}_{\text {day }^{-1}}$ in 69 days, when compared to the first year, with $729.65^{\circ} \mathrm{C}$ day $^{-1}$ during 61 days. For this stage, during the second crop year, besides the longer period, days with higher maximum temperatures were observed, which lead to an increase in the accumulated thermal time for this period. The maturation can be accelerated by high temperatures occurrence and, when associated with high humidity, contributed to seed lower quality. On the other hand, when associated to low humidity, mechanical damage can be observed on the seeds (FARIAS et al., 2007).

On Tables 1 and 2 the models of regression for the estimative of length for each soybean phenological stage during the 2012/2013 and 2013/2014 crop years are presented, based on the accumulated thermal time and the meteorological variables. A high correlation for the estimated duration of all phenological phases was observed during the crop years mainly due to the accumulated thermal time, with $\mathrm{R}^{2}$ values higher than $97 \%$. For the other meteorological variables, not all of them contributed to estimate the stages duration, and the ones that contributed, presented lower values, varying from $0.01 \%$ and $0.39 \%$. The phenological phases length can vary mainly according to temperature, and consequently, to the thermal time. 
Figure 2. Accumulated thermal sum for the stages sowing-emergency (S-E); emergency-final vegetative (E - FV); final vegetative-full bloom (FV- FB); and full bloom - phisiologic maturity (FP - PM) for the cultivars BMX Ativa RR, BMX Turbo RR and BMX Potência RR during the 2012/2013 and 2013/2014 crop years. UFSM, Frederico Westphalen/RS, Brazil, 2015.
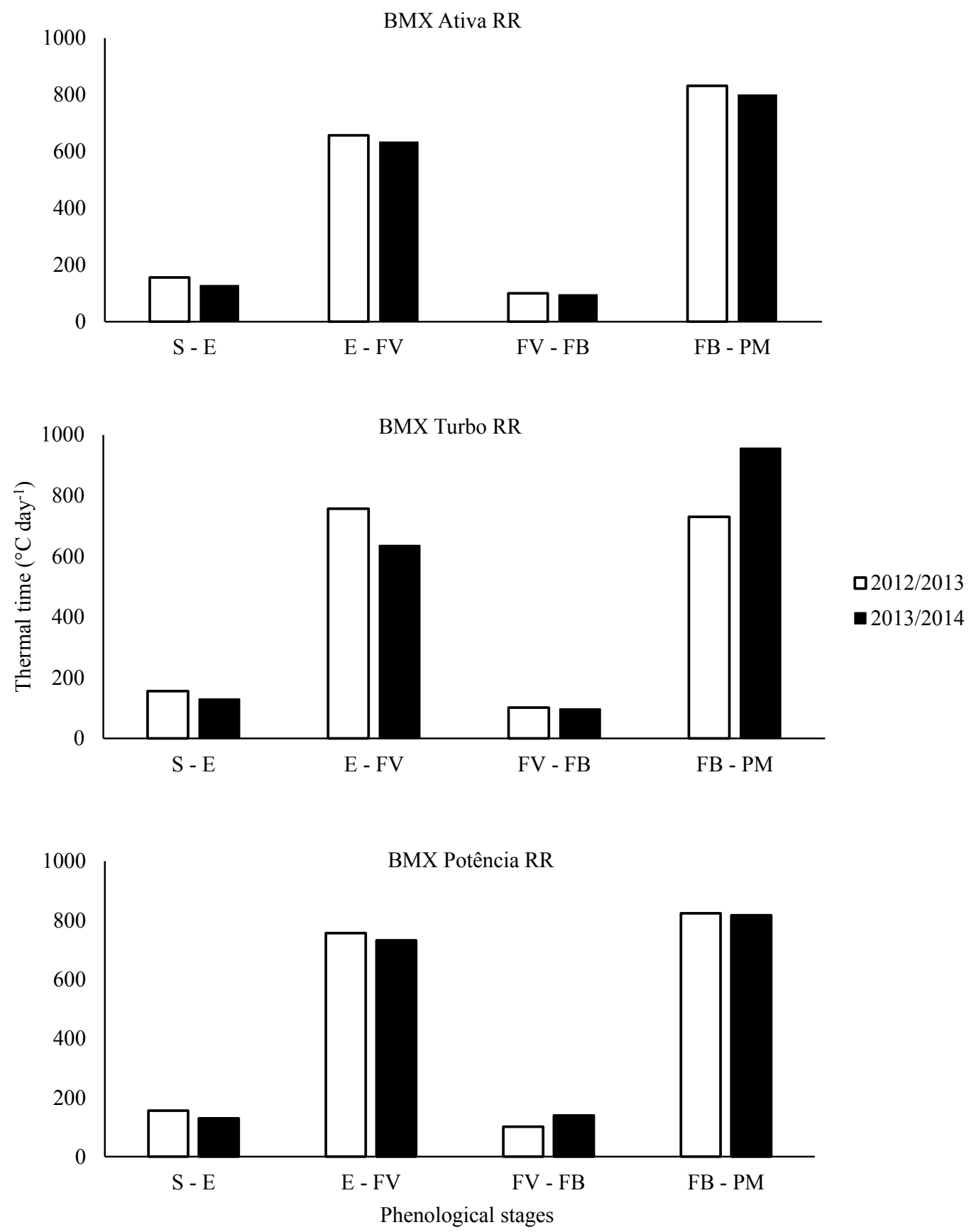
Table 1. Regression models of the soybean phenological stages for the cultivars BMX Ativa RR, BMX Turbo RR and BMX Potência RR: sowing - emergency ( $\mathrm{S}$ - E), emergency - final vegetative (E - FV), final vegetative - full bloom (FV-FB), full bloom - physiologic maturity (FB - PM), during the 2012/2013 crop year. Frederico Westphalen/RS, 2015, Brazil.

\begin{tabular}{|c|c|c|c|}
\hline $\begin{array}{l}\text { Phenological } \\
\text { stages }\end{array}$ & Regression model & $\mathbf{R}^{2}$ & $\%$ of contribution \\
\hline$S-E$ & $\begin{array}{l}=1.47818+0.00054417 \mathrm{Rad}-0.08457 \mathrm{Tmax}- \\
0.03127 \mathrm{Tmin}+0.05857 \mathrm{Tavg}+0.00222 \mathrm{Prec}+ \\
0.06542 \mathrm{Sta}\end{array}$ & 99.98 & $\begin{array}{l}\text { AcTT }=99.95 \% \\
\operatorname{Tmax}=0.02 \% \\
\operatorname{Rad}=0.01 \%\end{array}$ \\
\hline & $\begin{array}{l}=\mathrm{ATIVA}=0.30696+0.02644 \mathrm{Tmax}-0.08860 \mathrm{Tmin}+ \\
0.07205 \mathrm{AcTT}\end{array}$ & 99.96 & $\begin{array}{l}\text { AcTT }=99.95 \% \\
\text { Tmin }=0.01 \%\end{array}$ \\
\hline$E-F V$ & $\begin{array}{l}=\mathrm{TURBO} / \mathrm{POTEN} \mathrm{NCIA}=0.27183+0.02410 \mathrm{Tmax}- \\
0.08465 \mathrm{Tmin}+0.07217 \mathrm{AcTT}\end{array}$ & 99.97 & $\begin{array}{l}\text { AcTT }=99.96 \% \\
\text { Tmín }=0.01 \%\end{array}$ \\
\hline $\mathrm{FV}-\mathrm{FB}$ & $\begin{array}{l}=-0.01746-0.00081950 \mathrm{Rad}-0.15366 \mathrm{Tmax}- \\
0.19011 \mathrm{Tmin}+0.35998 \mathrm{Tavg}+0.07097 \mathrm{Sta}\end{array}$ & 98.52 & $\begin{array}{l}\text { AcTT }=97.55 \% \\
\text { Tmín }=0.15 \% \\
\text { Tavg }=0.11 \% \\
\operatorname{Tmax}=0.32 \% \\
\operatorname{Rad}=0.39 \%\end{array}$ \\
\hline \multirow{3}{*}{$\mathrm{FB}-\mathrm{PM}$} & $\begin{array}{l}=\text { ATIVA }=-4.99062+0.00383 \mathrm{Rad}+0.02630 \mathrm{Rain}+ \\
0.08341 \mathrm{AcTT}\end{array}$ & 99.61 & $\begin{array}{l}\text { AcTT }=99.51 \% \\
\operatorname{Rad}=0.07 \% \\
\text { Rain }=0.03 \%\end{array}$ \\
\hline & $\begin{array}{l}=\mathrm{TURBO}=-1.722039+0.00371 \mathrm{Rad}+0.28640 \mathrm{Tmax} \\
+0.46330 \mathrm{Tmin}-0.84025 \mathrm{Tavg}+0.01403 \text { Rain }+ \\
\text { 0.08452AcTT }\end{array}$ & 99.62 & $\begin{array}{l}\text { AcTT }=99.49 \% \\
\text { Rad }=0.06 \% \\
\text { Tmax }=0.01 \% \\
\text { Tmin }=0.01 \% \\
\text { Tavg }=0.04 \% \\
\text { Rain }=0.01 \%\end{array}$ \\
\hline & $\begin{array}{l}=\text { POTÊNCIA }=0.04078+0.00300 \mathrm{Rad}+ \\
0.30216 \mathrm{Tmax}+0.35168 \mathrm{Tmin}-0.84540 \mathrm{Tavg}+ \\
0.08540 \mathrm{AcTT}\end{array}$ & 99.66 & $\begin{array}{l}\text { AcTT }=99.54 \% \\
\operatorname{Rad}=0.06 \% \\
\text { Tavg }=0.03 \% \\
\text { Tmin }=0.01 \\
\text { Tmax }=0.02 \%\end{array}$ \\
\hline
\end{tabular}

$\mathrm{Rad}=$ solar radiation; $\mathrm{Tmax}=$ maximum temperature; $\mathrm{Tmin}=$ minimum temperature; Tavg= average temperature; Rain= rainfall; AcTT $=$ accumulated thermal time.

On Figures 3 and 4 the phenological stages are represented and also the mean data for the meteorological variables, stages duration and accumulated thermal time for the 2012/2013 and 2013/2014 crop years, respectively. The first crop year was characterized for higher maximum temperatures in almost all stages, with values between 34 and $35^{\circ} \mathrm{C}$. The minimum temperatures was also the lower compared to the follow crop year, for almost all stages. Differences were observed on the duration of the phenological stages according to cultivars and crop years, characterizing the air temperature influence, as observed by Souza et al. (2013). The lower stages were sowing - emergency, with nine days for both crop years and all cultivars and the final vegetative- full bloom stage, that 
varied from six to eight days. For both studied crop years, the stage sowing - emergency presented a favorable rainfall volume. For the same period, the accumulated thermal time was $155.45^{\circ} \mathrm{C}$ and $129.55^{\circ} \mathrm{C} \mathrm{day}^{-1}$, which conditioned the plants to a good thermal and hydric availability for the initial development. The stages emergency-final vegetative and full bloom - physiological maturation were the stages with a higher duration and, consequently, presented higher accumulated radiation, rainfall and thermal time.

Table 2. Regression models of the soybean phenological stages for the cultivars BMX Ativa RR, BMX Turbo RR and BMX Potência RR: sowing - emergency $(S-E)$, emergency - final vegetative (E - FV), final vegetative - full bloom (FV-FB), full bloom - physiologic maturity (FB - PM), during the 2013/2014 crop year. Frederico Westphalen/RS, 2015, Brazil.

\begin{tabular}{|c|c|c|c|}
\hline $\begin{array}{c}\text { Phenological } \\
\text { stages }\end{array}$ & Regression model & $\mathbf{R}^{2}$ & $\%$ of contribution \\
\hline$S-E$ & $\begin{array}{l}=0.28312-0.00056012 \mathrm{Rad}-0.04391 \mathrm{Tmax}+ \\
0.05118 \mathrm{Tmin}+0.07517 \mathrm{AcTT}\end{array}$ & 99.91 & $\begin{array}{l}\text { AcTT }=99.87 \% \\
\operatorname{Tmax}=0.02 \% \\
\operatorname{Rad}=0.01 \% \\
\operatorname{Tmin}=0.01 \%\end{array}$ \\
\hline \multirow{2}{*}{$E-F V$} & $\begin{array}{l}=\text { ATIVA } / \mathrm{TURBO}=1.82252+0.00077211 \mathrm{Rad}+ \\
0.03523 \mathrm{Tmax}-0.06135 \mathrm{Tmin}-0.10192 \mathrm{Tavg}- \\
0.00380 \mathrm{Rain}+0.06670 \mathrm{AcTT}\end{array}$ & 99.96 & $\begin{array}{l}\text { AcTT }=99.93 \% \\
\text { Tmin }=0.02 \% \\
\text { Rain }=0.01 \%\end{array}$ \\
\hline & $\begin{array}{l}=\text { POTÊNCIA }=2.42211+0.00058487 \mathrm{Rad}-0.09892 \mathrm{Tmin} \\
-0.04353 \mathrm{Tavg}-0.00469 \mathrm{Rain}+0.06643 \mathrm{AcTT}\end{array}$ & 99.98 & $\begin{array}{l}\text { AcTT }=99.95 \% \\
\operatorname{Tmin}=0.02 \% \\
\operatorname{Rad}=0.01 \%\end{array}$ \\
\hline \multirow[t]{2}{*}{$\mathrm{FV}-\mathrm{FB}$} & $\begin{array}{l}=\text { ATIVA } / \text { TURBO }=0.26926-0.72514 \text { Tmax }- \\
1.36901 \text { Tmin }+1.94492 \text { Tavg }+0.18399 \text { Rain }+ \\
\text { 0.07696AcTT }\end{array}$ & 1.00 & $\begin{array}{l}\text { AcTT }=99.69 \% \\
\text { Tmin }=0.24 \% \\
\text { Tavg }=0.01 \% \\
\text { Tmax }=0.05 \% \\
\text { Rain }=0.01 \%\end{array}$ \\
\hline & $\begin{array}{l}=\text { POTÊNCIA }=0.59083+0.00021369 \mathrm{Rad}+0.03003 \mathrm{Tmin} \\
-0.04763 \text { Tavg }+0.05733 \mathrm{AcTT}\end{array}$ & 99.98 & $\begin{array}{l}\text { AcTT }=99.95 \% \\
\text { Tavg }=0.02 \% \\
\text { Tmin }=0.01 \%\end{array}$ \\
\hline \multirow{3}{*}{$\mathrm{FB}-\mathrm{PM}$} & $=\mathrm{ATIVA}=-5.49591+0.00306 \mathrm{Rad}+0.07458 \mathrm{AcTT}$ & 99.35 & $\begin{array}{l}\text { AcTT }=99.29 \% \\
\operatorname{Rad}=0.06 \%\end{array}$ \\
\hline & $\begin{array}{l}=\mathrm{TURBO}=-8.59509+0.00460 \mathrm{Rad}+0.07937 \mathrm{Tmin}+ \\
0.07672 \text { AcTT }\end{array}$ & 99.57 & $\begin{array}{l}\text { AcTT }=99.44 \% \\
\operatorname{Rad}=0.12 \% \\
\operatorname{Tmin}=0.01 \%\end{array}$ \\
\hline & $\begin{array}{l}=\text { POTÊNCIA }=-6.71679+0.00171 \mathrm{Rad}+0.07488 \mathrm{Tmax} \\
+0.07962 \mathrm{AcTT}\end{array}$ & 99.82 & $\begin{array}{l}\text { AcTT }=99.76 \% \\
\operatorname{Rad}=0.05 \% \\
\operatorname{Tmax}=0.01 \%\end{array}$ \\
\hline
\end{tabular}

$\mathrm{Rad}=$ solar radiation; $\mathrm{Tmax}=$ maximum temperature; $\mathrm{Tmin}=$ minimum temperature; Tavg= average temperature; Rain= rainfall; AcTT $=$ accumulated thermal time 
Besides the meteorological variation for the stages, the flowering soybean date is different for each year, according to temperature (EMBRAPA, 2004), which confirms the influence of this element on the development (WU et al., 2015). Photoperiod and temperature are the main environmental factors that can determine the soybean flowering and to understand the genotypes photothermal response is important to consider the characteristics that are associated to environment resources (WU et al.,
2015). The simulations on air temperature changes shows a direct influence on the phenological stages duration in soybean. Kumagai and Sameshima (2014) detected that the duration from days of sowing to the beginning of soybean flowering decreased with an increase in temperature for all studied cultivars. Thus, an increase of the flowering period with a consequently increase in the number of open flowers, could result in an increase in pods and grains for late maturity cultivars.

Figure 3. Meteorological elements and bioclimate index for the soybean development stages sowing - emergency (S - E), emergency - final vegetative (E - FV), final vegetative - full bloom (FV-FB), full bloom - physiologic maturity (FB - PM) for the cultivars BMX Ativa RR (a), BMX Turbo RR (b) and BMX Potência RR (c) during the 2012/2013 crop year, Frederico Westphalen/RS, Brazil, 2015.
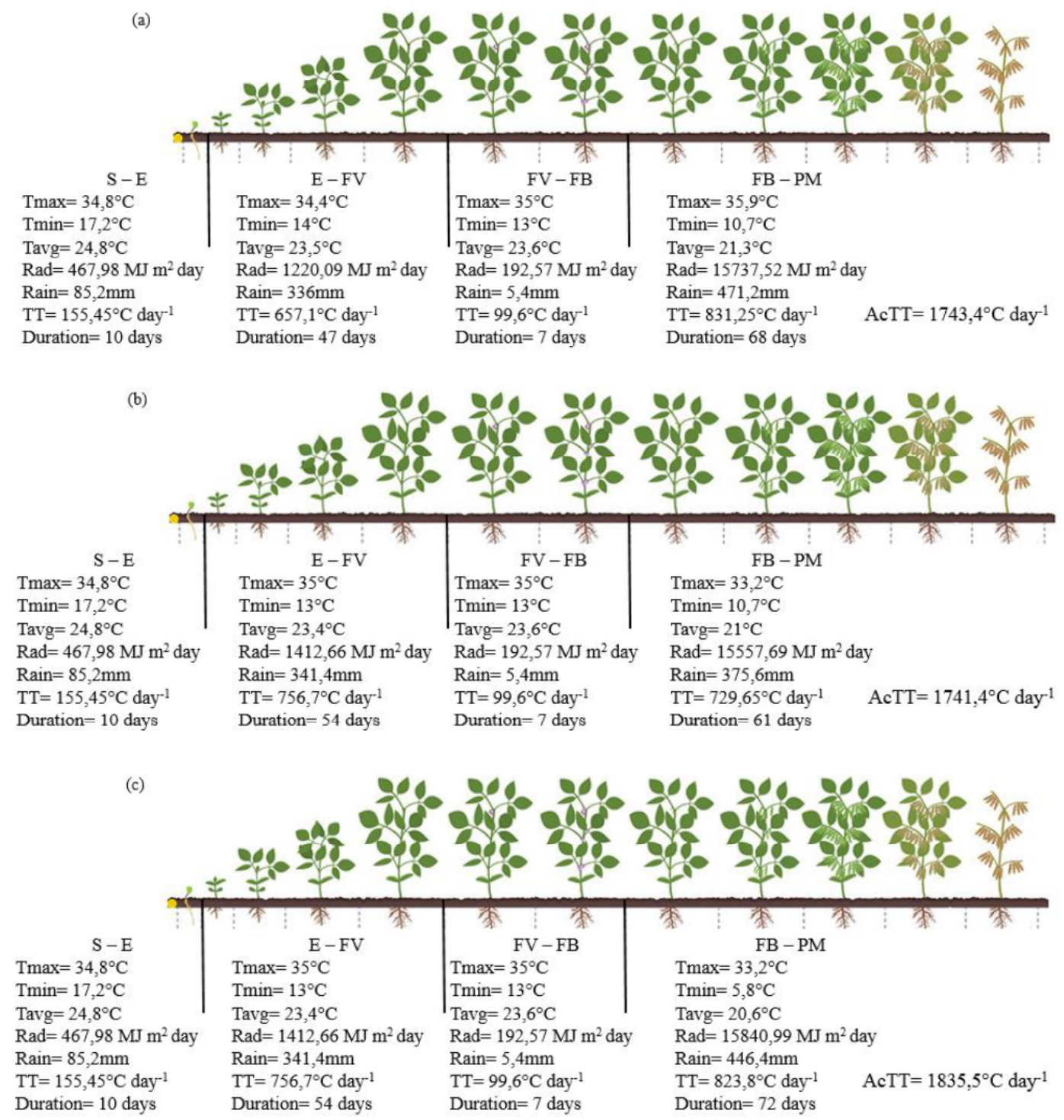

Source: Adapted from Bayer (2015). 
Because of the annual meteorological variation and the cultivars characteristics, the length of the phenological stages in soybean varied according to the sowing time. Zanon et al. (2015) observed a reduction on the vegetative stage when the soybean was sown before or after the recommended date, and the reproductive stage reduced with the sowing delay for most studied cultivars. In addition to it, cultivars with indeterminate growth habit presented a longer overlap period of the vegetative and reproductive stages when compared to determinate cultivars, for all species and growing places, favoring the growers choice. Thus, is important the development of studies that consider new commercial cultivars, since most of them have an indeterminate growth habit, with an early cycle and the sowing is concentrated in October and November for the Rio Grande do Sul state, Brazil.

Figure 4. Meteorological elements and bioclimate index for the soybean development stages sowing - emergency (S - E), emergency - final vegetative (E - FV), final vegetative - full bloom (FV-FB), full bloom - physiologic maturity (FB - PM) for the cultivars BMX Ativa RR (a), BMX Turbo RR (b) and BMX Potência RR (c) during the 2013/2014 crop year, Frederico Westphalen/RS, Brazil, 2015.
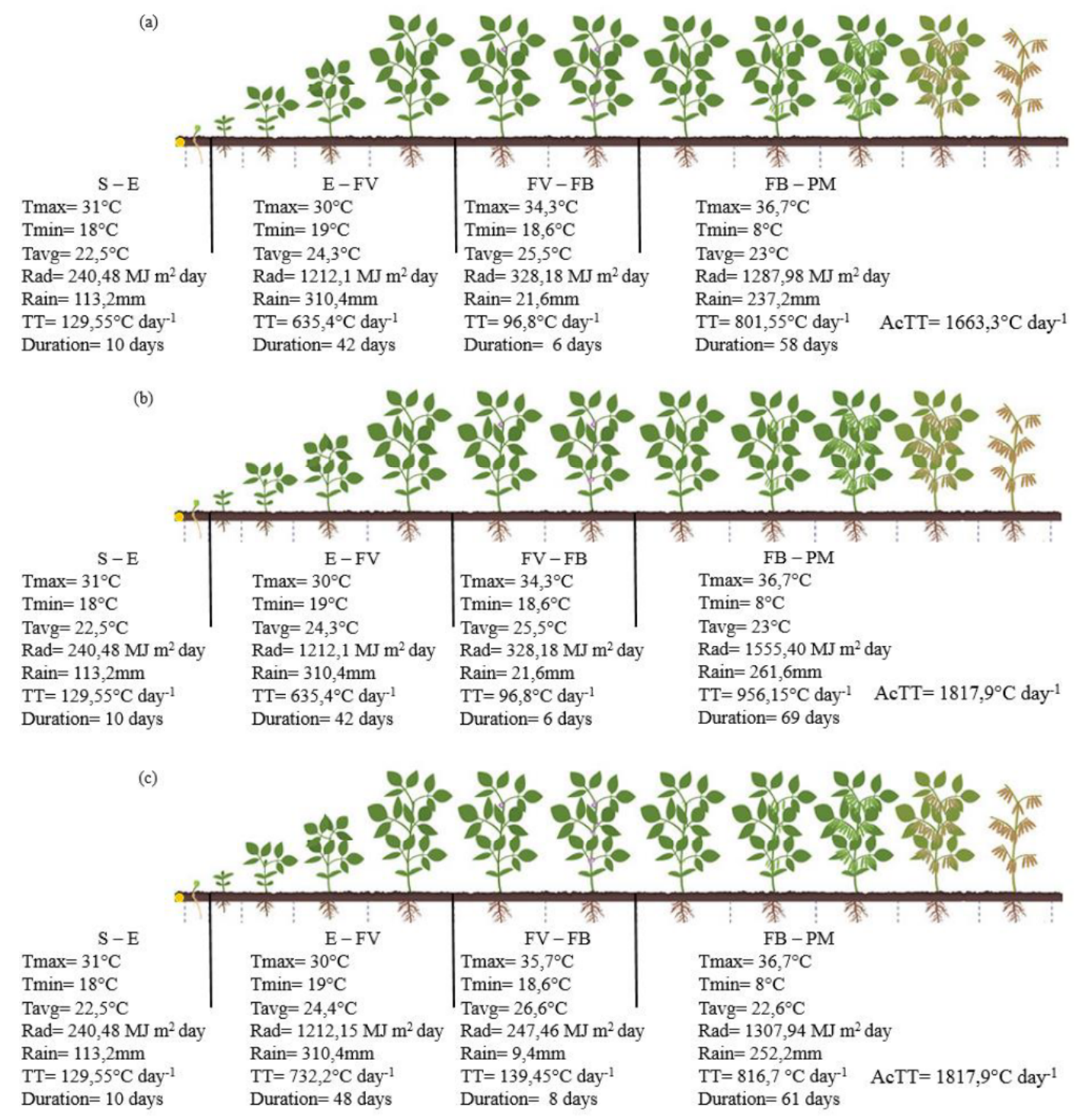

Source: Adapted from Bayer (2015). 
The air temperature can influence soybean growth and development. The accumulated thermal time varied over the crop year and according to cultivars, and it is the main contributor to estimate the phenological stages length.

\section{References}

BAYER. De primeira sem dúvida - FOX. [S.1.:s.n.], 2015. Available at: $<$ http://www.deprimeirasemduvida. com.br/estacao?id=2> Accessed at: 12 jan 2015.

CARGNELUTTI FILHO, A.; MATZENAUER, R.; MALUF, J. R. T.; RADIN, B. Variabilidade temporal e espacial da precisão das estimativas de elementos meteorológicos no Rio Grande do Sul. Ciência Rural, Santa Maria, v. 39, n. 4, p. 962-970, 2009.

CARON, B. O.; MANFRON, P. A.; LÚCIO, A. D.; SCHMIDT, D.; MEDEIROS, S. L. P.; BONNECARRÈRE, R. A. G.; DOURADO NETO, D. Equações de estimativa da fitomassa da parte aérea da alface. Ciência Rural, Santa Maria, v. 37, n. 5, p. 12481254, 2007

COMISSÃO DE QUÍMICA E FERTILIDADE DO SOLO RS/SC - CQFS RS/SC. Manual de adubação e calagem para estados do Rio Grande do Sul e Santa Catarina, SBCS/NRS. 10. ed. Porto Alegre: Evangraf, 2004. 400 p.

COSTAMILAN, L. M.; PANIZZI-CARRÃO, M. C.; STRIEDER, M. L.; BERTAGNOLLI, P. F. (Org.). Indicações técnicas para a cultura da soja no Rio Grande do Sul e Santa Catarina safras 2012/2013 e 2013/2014. In: REUNIÃO DE PESQUISA DE SOJA DA REGIÃO SUL, 39., 2012, Passo Fundo. Anais... Passo Fundo: Embrapa Trigo, 2012. p. 142.

EMPRESA BRASILEIRA DE PESQUISA AGROPECUÁRIA - EMBRAPA. Sistema brasileiro de classificação de solos. 2. ed. Rio de Janeiro: EMBRAPASPI, 2006. 412 p.

Tecnologias de produção de soja, região central do Brasil. Embrapa Soja, Sistemas de Produção. Londrina: Embrapa, 2004. n. 1. Disponível em: <http:// www.cnpso.embrapa.br/producaosoja/exigencias.htm>. Acesso em: 18 dez. 2014.

FARIAS, J. R. B.; NEPOMUCENO, A. L.; NEUMAIER, N. Ecofisiologia da soja. Londrina: EMBRAPA, set. 2007. (Circular técnica, 48).
FARIAS, J. R. B.; NEUMAIER, N.; NEPOMUCENO, A. L. Soja. In: MONTEIRO, J. E. B. A. Agrometeorologia dos cultivos: o fator meteorológico na produção agrícola. Brasília: INMET, 2009. cap. 15, p. 261-278.

FEHR, W. R.; CAVINESS, C. E. Stages of soybean development. Ames: Iowa State University of science and Techonology, 1977. 11 p. (Special Report, 80).

FERREIRA, W. P. M.; COSTA, L. C.; SOUZA, C. de F. Modelo de estimativa de produtividade de soja $\{$ Glycine $\max ($ L.) Merril\} em função da variabilidade da temperatura. Engenharia na Agricultura, Viçosa, MG, v. 15, n. 4, p. 400-407, 2007.

GILMORE, E. C.; ROGERS, J. S. Heat units as a method of measuring maturity in corn. Agronomy Journal, Madison, v. 50, n. 10, p. 611-615, 1958.

KANTOLIC, A. G. Control ambiental y genético de la fenologia del cultivo de soja: impactos sobre el rendimento y la adaptación de genótipos. Revista de la Facultad de Agronomia, Buenos Aires, v. 28, n. 1, p. 6388, 2008.

KUMAGAI, E.; SAMESHIMA, R. Genotypic differences in soybean yeld responses to increasing temperature in a cool climate are related to maturity group. Agricultural and Forest Meteorology, Connecticut, v. 198-199, n. 6, p. 265-272, 2014.

PIPER, E. Camparison of two phenology models for predicting flowering and maturity date of soybean. Crop Science, Madison, v. 36, n. 6, p. 1606-1614, 1996.

RICHTER, G. L.; ZANON JÚNIOR, A.; STRECK, N. A.; GUEDES, J. V. C.; KRÄULICH, B.; ROCHA, T. S. M. da; WINCK, J. E. M.; CERA, J. C. Estimativa da área de folhas de cultivares antigas e modernas de soja por método não destrutivo. Bragantia, Campinas, v. 73, n. 4, p. 416-425, 2014.

ROCHA, R. S.; SILVA, J. A. L. da; NEVES, J. A.; SEDIYAMA, T.; TEIXEIRA, R. de C. Desempenho agronômico de variedades e linhagens de soja em condições de baixa latitude em Teresina - PI. Revista Ciência Agronômica, Fortaleza, v. 43, n. 1, p. 154-162, 2012.

RODRIGUES, O.; DIDONET, A. D.; LHAMBY, J. C. B.; BERTAGNOLLI, P. F.; LUZ, J. S. da. Resposta quantitativa do florescimento da soja à temperatura e ao fotoperíodo. Pesquisa Agropecuária Brasileira, Brasília, v. 36, n. 3, p. 431-437, 2001.

SEDIYAMA, T. (Org.). Tecnologias de produção e usos da soja. Londrina: Mecenas, 2009. 314 p. 
SETIYONO, T. D.; WEISS, A.; SPECHT, J.; BASTIDAS, A. M.; CASSMAN, K. G.; DOBERMANN, A. Understanding and modeling the effect of temperature and daylength on soybean phenology under high-yield conditions. Field Crops Research, Aberdeenshire, v. 100, n. 2, p. 257-271, 2007.

SOUZA, P. J. de O. P. de; SOUZA, A. M. L. de; SAMPAIO, L. S. Soybean development and termal requerimento under the climatic conditions of Paragominas, Pará State, Brazil. Revista de Ciências Agrárias, Belém, v. 56, n. 4, p. 371-375, 2013.

STATISTICAL ANALYSIS SYSTEM INSTITUTE SAS. Getting started with the SAS Learning Edition. Version 8,0. Cary: SAS Inst, 2003. 200 p.

STRECK, N. A.; PAULA, G. M. de; CAMERA, C.; MENEZES, N. L. de; LAGO, I. Estimativa do plastocrono em cultivares de soja. Bragantia, Campinas, v. 67, n. 1, p. 67-73, 2008.

STRIEDER, M. L.; PIRES, J. L. F.; COSTAMILAN, L. M.; FAGANELLO, A.; VARGAS, L.; BERTAGNOLLI, P. F.; CORASSA, G. M. Rendimento de grão de soja em diferentes arranjos de planta, safra 2012/2013. In: COSTAMILAN, L. M.; CARRÃO-PANIZZI, M. C.
(Ed.). Soja: resultados de pesquisa 2012/2013. Passo Fundo: Embrapa Trigo, out. 2013. 19 p. (Documentos Online, 145).

WAGNER, M. V.; JADOSKI, S. O.; LIMA, A. dos S.; MAGGI, M. F.; POTT, C. A.; SUCHORONCZEK, A. Avaliação do ciclo fenológico da cultura do milho em função da soma térmica em Guarapuava, Sul do Brasil. Pesquisa Aplicada \& Agrotecnologia, Guarapuava, v. 4, n. 1, p. 135-149, 2011.

WU, T. T.; LI, J.; WU, C.; SUN, S.; MAO, T.; JIANG, B.; HOU, W.; HAN, T. Analysis of the independet-and interactive -photo-thermal effects on soybean flowering. Journal of Integrative Agriculture, Pequim, v. 14, n. 4, p. 622-632, 2015.

ZANON, A. J.; WINCK, J. E. M.; STRECK, N. A.; ROCHA, T. S. M. da; CERA, J. C.; RICHTER, G. L.; LAGO, I.; SANTOS, P. M. de; MACIEL L. da R.; GUEDES, J. V. C.; MARCHESAN, E. Desenvolvimento de cultivares de soja em função do grupo de maturação e tipo de crescimento em terras altas e terras baixas. Bragantia, Campinas, v. 74, n. 4, p. 400-411, 2015. 